thousand Japanese scientific workers, representing all fields of research, are participating in the election of 210 members for the country's first National Science Council. This election, due on December 20 , is considered to be of unusual interest as it is thought to represent the first attempt of scientific workers of any country as a whole to elect members of its supreme scientific organ. The mission is expected to review progress made by Japanese men of science in the development of democratic national organisations for scientific activity. It is expected to bring up to date the report submitted by the previous advisory group ; recommendations by that group served as guides to 'SCAP' sections in judging proposals of the Japanese for the reorganisation of national scientific bodies. The group proposes to spend approximately one day each in Sendai, Sapporo, Kyoto and Hiroshima; the remainder of the time will be spent in Tokyo in discussion with 'SCAP' personnel and Japanese scientific workers.

\section{Vacation Work for Technical Students}

THE fourteenth annual report for the year ending October 1948 by the Vacation Work Scheme of the Imperial College of Science and Technology has recently been published. The Scheme aims at providing work in Great Britain and abroad for students during their vacation, and it is almost entirely voluntary in nature. During 1948, 829 students participated as compared with 705 in 1947 (this increase being largely due to a greater number of overseas students); and this year's total was made up of 200 overseas students and 629 British, 194 of these latter having worked abroad. The bulk of the British students (591 in actual number) was drawn from the three Colleges which form the Imperial College, namely, the Royal College of Science, Royal School of Mines, and City and Guilds College. In January 1948 an international conference was held in London at the Imperial College to unify the procedure and minimize the corrospondence for the exchange of students between different States; ten countries sent representatives and an organisation was founded called the International Association for the Exchange of Students for Technical Experience. During the recent summer vacation this Association has successfully exchanged 950-1,000 students between the participating countries. The next conference of this Association will be held in Copenhagen during January $3-7,1949$. As a result of the establishment of this Association, central organisations have been set up in each country; the governors of the Imperial College have decided to broaden their machinery, coping with international exchange, to include undergraduates from other universities and colleges in Great Britain, and this information has already been communicated. The aim is to make the scheme self-supporting, if possible, through an affiliation fee payable by each college concerned (based on the number of students sent abroad) together with a registration fee payable by the student. Offers of financial assistance have already been made by Messrs. Lever Brothers and Unilever, Ltd., Rolls Royce, Ltd., and the National Oil Refineries, Ltd., and it is anticipated that the scheme will be in operation for the summer of 1949.

\section{Management Abstracts}

For these days, Management Abstracts, the first issue of a series of specialized publications dealing with the different aspects of management to be published by the British Institute of Management
(London), seems rather a lavish production. It covers some two hundred British and Overseas publications dealing with current developments in management seience, and the abstracts are classified under such headings as general management and organisation; works management; personnel and welfare; financial management ; distribution; supplies; transport ; statistics; public administration; education and training. Management Abstracts will be issued monthly and is intended to cover, eventually, material published in any part of the world; but on its present scale such cover can scarcely be obtained without very considerable expansion on the first two issues. The basis of selection of the abstracts is not apparent, although the more important articles published in Great Britain in recent months appear to be included. For the annual subscription of $30 s$. (or $3 s$. per copy) the business executive may, as it is elaimed, save some time; but the production is unlikely to give him much that he cannot readily obtain, and probably earlier, from an efficient firm's library. The publication also includes "Book Notes", which are brief and mainly descriptive. This section might perhaps be expanded with advantage and the length of the abstracts curtailed, particularly if the latter were made purely descriptive and not, as in these two issues, in part critical.

\section{Milk : from Cow to Consumer}

Wallace Productions, Ltd., have just finished making a documentary film for the United Dairies, Ltd. This film, which lasts for about half an hour, is called "The Milky Way" and was shown to a small invited audience on November 30 at the British Council Theatre in London. It tells the story of the production, pasteurization and distribution of milk under modern conditions with particular reference to London (the United Dairies, Ltd., being one of the major suppliers of milk in the London area); but the theme is representative of any large town or city where rigid precautions are taken with regard to the safety and purity of mills. The general scientific level of the film has been designed for showing to student-nurses and the senior science forms of secondary schools; but it can be recommended to any intelligent person, scientific or otherwise. The emphasis stressed throughout is on hygiene ; but the full account of milk from cow to consumer is amply and well told. The makers and sponsors of this documentary film are to be congratulated on a production which has entertainment value as well as scientific and educational interest.

\section{Information Services Committee}

Arising out of the Scientific Information Conference held last June, the Council of the Royal Society has set up a Standing Committee on Information Services. The terms of reference are: (1) to advise on means of improving existing methods of publishing, abstracting, indexing and distributing scientific information and, in particular, to advise on the implementation of the recommendations of the Royal Society Scientific Information Conference; (2) to report to the Council of the Royal Society.

The following have agreed to serve on the committee : Sir Alfred Egerton (chairman); the Treasurer and the Secretaries of the Royal Society; Dr. T. E. Allibone; Prof. J. D. Bernal ; Dr. G. L. Brown; Sir David Chadwick; Mr. J. E. Cummins ; Dr. G. M. Findlay; Dr. J. E. Holmstrom ; Dr. A. King ; Dr. J. G. Malloch; and Dr. C. F. A. Pantin. 